\title{
Rent-Shifting Export Subsidies with an Imported Intermediate Product
}

\author{
一橋大学 石川 城太 \\ ブリティシュ・コロンビア大学Ｂarbara J. Spencer
}

本研究は，戦略的貿易政策の枠組みに不完全競争のもとで生産される中間財を明示的 に組み込むことによって戦略的貿易政策の議論がどのような影響を受けるかを分析した ものである。特に，分析の対象を輸出補助金（specific export subsidy）に絞った。その ために，輸出補助金政策の代表的モデルである Brander-Spencer モデルに中間財を導入 し，かつ中間財市場も最終財市場と同様にクールノー競争のもとにあるようなモデルを 構築した。

本研究での 3 つの問題意識, 及びそれに対して得られた主な結果は以下のとおりであ る。

1 ，最終財市場及び中間財市場がともに寡占的な競争状態にあるとき，最終財に対する 自国の輸出補助金から生じる最終的なレントはだれに帰着するのか。

結果：自国の最終財輸出補助金から生じるレントは，かなり緩い条件のもとで最終財生 産者のみならず，中間財生産者にも渡ることになる。したがって，中間財が海外から輸 入されている場合，自国政府が自国の経済厚生を高めるために最終財輸出補助金を供与 しているとすれば，それを供与するインセンティブは弱くなる。

2 , 中間財市場が寡占的な場合，それが完全競争的な場合と比較して，最終財への輸出 補助金供与が結果として自国の経済厚生を高める可能性は高くなるのか，あるいは低く なるのか。

結果：中間財市場がクールノー競争のもとにあるような場合，そのような可能性が高く なることがある。特に，最終財が戦略的補完のケースでも最適な補助金は正となりうる。 3 , 最終財への輸出補助金政策と同様な効果を中間財に対する何らかの政策によって得 ることができるか。

結果：中間財に対して輸出補助金と同率の輸入関税（specific tariff）及び（自国の生産 に対しては）生産補助金（specific production subsidy）という組み合わせの政策を採れば, 最終財への輸出補助金政策と全く同一の効果を得ることができる。ただし，輸入関税と 生産補助金の率が同一であるという条件を外せば，輸出補助金のみの場合よりも輸入関 
税と生産補助金の組み合わせの方がより高い経済厚生を達成できる。 *フルペーパーは NBER Working Paper Series No. 5458 である。 